\title{
Front matter: Volume 10385
}

, "Front matter: Volume 10385," Proc. SPIE 10385, Advances in Metrology for X-Ray and EUV Optics VII, 1038501 (25 October 2017); doi:

10.1117/12.2297021

SPIE Event: SPIE Optical Engineering + Applications, 2017, San Diego, California, United States 


\title{
PROCEEDINGS OF SPIE
}

\section{Advances in Metrology for X-Ray and EUV Optics VII}

\author{
Lahsen Assoufid \\ Haruhiko Ohashi \\ Anand Khrishna Asundi \\ Editors
}

6-7 August 2017

San Diego, California, United States

Sponsored and Published by

SPIE 
The papers in this volume were part of the technical conference cited on the cover and title page. Papers were selected and subject to review by the editors and conference program committee. Some conference presentations may not be available for publication. Additional papers and presentation recordings may be available online in the SPIE Digital Library at SPIEDigitalLibrary.org.

The papers reflect the work and thoughts of the authors and are published herein as submitted. The publisher is not responsible for the validity of the information or for any outcomes resulting from reliance thereon.

Please use the following format to cite material from these proceedings:

Author(s), "Title of Paper," in Advances in Metrology for X-Ray and EUV Optics VII, edited by Lahsen Assoufid, Haruhiko Ohashi, Anand Khrishna Asundi, Proceedings of SPIE Vol. 10385 (SPIE, Bellingham, WA, 2017) Seven-digit Article CID Number.

ISSN: 0277-786X

ISSN: 1996-756X (electronic)

ISBN: 9781510612273

ISBN: 9781510612280 (electronic)

Published by

SPIE

P.O. Box 10, Bellingham, Washington 98227-0010 USA

Telephone +1 3606763290 (Pacific Time) · Fax +1 3606471445

SPIE.org

Copyright @ 2017 , Society of Photo-Optical Instrumentation Engineers.

Copying of material in this book for internal or personal use, or for the internal or personal use of specific clients, beyond the fair use provisions granted by the U.S. Copyright Law is authorized by SPIE subject to payment of copying fees. The Transactional Reporting Service base fee for this volume is $\$ 18.00$ per article (or portion thereof), which should be paid directly to the Copyright Clearance Center (CCC), 222 Rosewood Drive, Danvers, MA 01923. Payment may also be made electronically through CCC Online at copyright.com. Other copying for republication, resale, advertising or promotion, or any form of systematic or multiple reproduction of any material in this book is prohibited except with permission in writing from the publisher. The CCC fee code is 0277 $786 \times / 17 / \$ 18.00$.

Printed in the United States of America.

Publication of record for individual papers is online in the SPIE Digital Library.

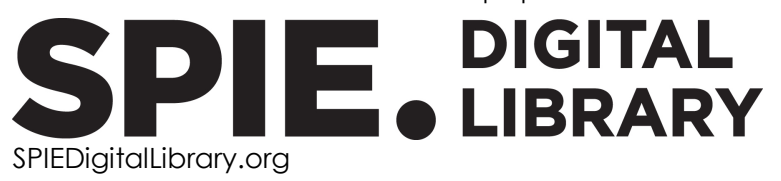

Paper Numbering: Proceedings of SPIE follow an e-First publication model. A unique citation identifier (CID) number is assigned to each article at the time of publication. Utilization of CIDs allows articles to be fully citable as soon as they are published online, and connects the same identifier to all online and print versions of the publication. SPIE uses a seven-digit CID article numbering system structured as follows:

- The first five digits correspond to the SPIE volume number.

- The last two digits indicate publication order within the volume using a Base 36 numbering system employing both numerals and letters. These two-number sets start with 00, 01, 02, 03, 04, 05, 06, 07, 08, 09, OA, OB ... 0Z, followed by 10-1Z, 20-2Z, etc. The CID Number appears on each page of the manuscript. 


\title{
Contents
}

\author{
$\checkmark$ Authors \\ vii Conference Committee
}

\section{SESSION 1 AT-WAVELENGTH METROLOGY}

1038502 Single-grating Talbot imaging for wavefront sensing and $x$-ray metrology [10385-1]

1038504 Speckle-based portable device for in-situ metrology of $x$-ray mirrors at Diamond Light Source [10385-3]

1038505 Investigation of HF-plasma-treated soft x-ray optical elements [10385-4]

\section{SESSION 2 METROLOGY OF VLS GRATINGS}

1038506 Intrinsic resolving power of XUV diffraction gratings measured with Fizeau interferometry [10385-5]

1038507 Characterization of a $150-\mathrm{mm}$ long variable line spacing plane grating through interferometry [10385-7]

1038508 Metrology of variable-line-spacing x-ray gratings using the APS Long Trace Profiler [10385-8]

\section{SESSION 3 CALIBRATION AND NANORADIAN METROLOGY}

1038509 Recent developments in nanoradian-angle metrology [10385-9]

10385 0A A new ultra-high-accuracy angle generator: current status and future direction [10385-10]

$10385 \mathrm{OB}$ A portable device for calibration of autocollimators with nanoradian precision [10385-11]

SESSION 4 METROLOGY FACILITIES

10385 OC A new optics metrology laboratory at CNPEM: metrology capabilities, performance, and future plans [10385-12]

\section{SESSION 5 NOVEL INSTRUMENTS AND METHODS}

10385 OG Development of a high performance surface slope measuring system for two-dimensional mapping of $\mathbf{x}$-ray optics [10385-16] 
$10385 \mathrm{OH}$ Surface slope metrology of highly curved x-ray optics with an interferometric microscope [10385-18]

10385 ol New twist in the optical schematic of surface slope measuring long trace profiler [10385-19]

SESSION 6 STITCHING AND SUB-NANOMETER SURFACE METROLOGY

10385 OM Development of relative angle determinable stitching interferometry for high-accuracy $\mathbf{x}$ ray focusing mirrors [10385-20]

10385 ON Fizeau stitching at the European Synchrotron Radiation Facility (ESRF) [10385-21]

1038500 Three-dimensional shape measurement for $\mathbf{x}$-ray ellipsoidal mirror [10385-22]

POSTER SESSION

$103850 Q \quad X$-ray multilayer mid-frequency characterizations using speckle scanning techniques [10385-25] 


\section{Authors}

Numbers in the index correspond to the last two digits of the seven-digit citation identifier (CID) article numbering system used in Proceedings of SPIE. The first five digits reflect the volume number. Base 36 numbering is employed for the last two digits and indicates the order of articles within the volume. Numbers start with 00, 01, 02, 03, 04, 05, 06, 07, 08, 09, 0A, 0B...0Z, followed by 10-1Z, 20-2Z, etc.

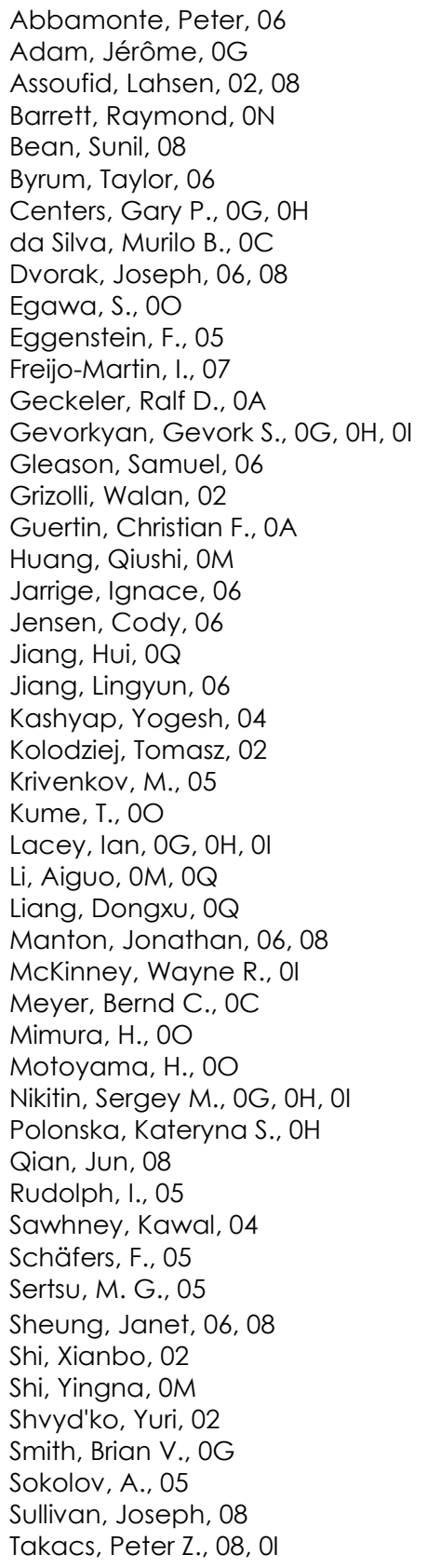

Takei, Y., 00

Thomasset, Muriel, 08

Tian, Naxi, OQ

Vannoni, M., 07

Varykhalov, A., 05

Vivo, Amparo, ON

Wang, Hongchang, 04

Wang, Hua, OM, OQ

Wang, Zhanshan, $\mathrm{OM}$

Wolf, J., 05

Xu, Xudong, OM

Yamaguchi, G., 00

Yan, Shuai, $O Q$

Yandayan, Tanfer, 09, OB

Yashchuk, Valeriy $\mathrm{V} ., \mathrm{OG}, \mathrm{OH}, \mathrm{Ol}$

Zeschke, T., 05

Zhang, Ling, $O M$

Zhou, Tunhe, 04 
Proc. of SPIE Vol. 10385 1038501-6

Downloaded From: https://www.spiedigitallibrary.org/conference-proceedings-of-spie on 26 Apr 2023 Terms of Use: https://www.spiedigitallibrary.org/terms-of-use 


\title{
Conference Committee
}

\author{
Conference Chairs
}

Lahsen Assoufid, Argonne National Laboratory (United States)

Haruhiko Ohashi, Japan Synchrotron Radiation Research Institute (Japan)

Anand Krishna Asundi, Nanyang Technological University (Singapore)

Program Track Chairs

Ali M. Khounsary, Illinois Institute of Technology (United States)

Ralph B. James, Savannah River National Laboratory (United States)

Conference Program Committee

Simon G. Alcock, Diamond Light Source Ltd. (United Kingdom)

Raymond Barrett, European Synchrotron Radiation Facility (France)

Daniele Cocco, SLAC National Accelerator Laboratory

(United States)

Uwe Flechsig, Paul Scherrer Institut (Switzerland)

Ralf D. Geckeler, Physikalisch-Technische Bundesanstalt (Germany)

Kenneth A. Goldberg, Lawrence Berkeley National Laboratory (United States)

Mikhail V. Gubarev, NASA Marshall Space Flight Center (United States)

Christian F. Guertin, Vermont Photonics Technologies Corporation (United States)

Mourad Idir, Brookhaven National Laboratory (United States)

Weiguo Liu, Xi'an Technological University (China)

Jonathan Manton, Inprentus, Inc. (United States)

Hidekazu Mimura, The University of Tokyo (Japan)

Josep Nicolas, CELLS - ALBA (Spain)

Lorenzo Raimondi, Elettra-Sincrotrone Trieste S.C.p.A. (Italy)

Rajdeep Singh Rawat, National Institute of Education (Singapore)

Kawal Sawhney, Diamond Light Source Ltd. (United Kingdom)

Frank Siewert, Helmholtz-Zentrum Berlin für Materialien und Energie GmbH (Germany)

Regina Soufli, Lawrence Livermore National Laboratory (United States)

Daniele Spiga, INAF - Osservatorio Astronomico di Brera (Italy)

Peter Z. Takacs, Brookhaven National Laboratory (United States)

Muriel Thomasset, Synchrotron SOLEIL (France)

Maurizio Vannoni, European XFEL GmbH (Germany) 
Amparo Vivo, European Synchrotron Radiation Facility (France)

Zhanshan Wang, Tongji University (China)

Kazuto Yamauchi, Osaka University (Japan)

Tanfer Yandayan, TUBITAK UME (Turkey)

Valeriy V. Yashchuk, Lawrence Berkeley National Laboratory (United States)

Brian W. Yates, Canadian Light Source Inc. (Canada)

\section{Session Chairs}

1 At-Wavelength Metrology

Lahsen Assoufid, Argonne National Laboratory (United States)

2 Metrology of VLS Gratings

Kazuto Yamauchi, Osaka University (Japan)

3 Calibration and Nanoradian Metrology

Lahsen Assoufid, Argonne National Laboratory (United States)

4 Metrology Facilities

Anand Krishna Asundi, Nanyang Technological University (Singapore)

5 Novel Instruments and Methods

Kazuto Yamauchi, Osaka University (Japan)

6 Stitching and Sub-Nanometer Surface Metrology

Kazuto Yamauchi, Osaka University (Japan) 